\title{
ZMIANY STOSUNKÓW WŁASNOŚCIOWYCH W POLSCE PO ROKU 1989
}

Dwudziesta piąta rocznica upadku systemu komunistycznego stwarza okazję do próby oceny transformacji rynkowej w Polsce, zwłaszcza oceny jej rezultatów gospodarczych i społecznych. Wszystkim przemianom towarzyszyła aktywność prawodawcy, który z lepszym lub gorszym skutkiem tworzył prawne ramy dla bezprecedensowych przeobrażeń sfery własnościowej i organizacyjnej polskiej gospodarki. Warto więc przypomnieć podstawowe akty prawne, które zadecydowały o obecnym, formalnoprawnym wymiarze systemu gospodarczego, a szczególnie o zmianach stosunków własnościowych.

\section{EWOLUCJA REGULACJI KONSTYTUCYJNYCH}

Punktem odniesienia polskiego konstytucjonalizmu jest Konstytucja marcowa uchwalona 21 marca $1921 \mathrm{r}$. Wśród praw chronionych Ustawą zasadniczą znalazła się wyrażona w art. 99 zasada poszanowania własności. Ograniczenie własności mogło nastapić tylko na drodze ustawowej i ze względów publicznych. Regulacja ta została utrzymana w mocy przez Konstytucję z 1935 r.

Po II wojnie światowej w Konstytucji z 1952 r. narzucono formułę państwa socjalistycznego, w którym prawo formalnie było wyrazem woli i interesów ludu pracującego. Podstawę ustroju stanowiły uspołecznione środki produkcji, a państwo posiadało monopol na handel zagraniczny. Najważniejszą kategorią mienia było mienie ogólnonarodowe, do którego zaliczano zarówno zasoby naturalne, przedsiębiorstwa, jak i inne dobra, np. środki transportu. Do Konstytucji wpisano także planowy charakter gospodarki. Odnosząc się do własności prywatnej, Konstytucja z 1952 r. stanowiła jedynie o ochronie własności osobistej obywateli. W zakresie dotyczącym prywatnych środków produkcji wprowadzono natomiast konstrukcję „uznania i ochrony”, w granicach obowiazujących ustaw, indywidualnej własności ziemi i innych środków produkcji należących do chłopów i rzemieślników.

Po odrzuceniu poprzedniej formacji ustrojowej zasadnicze znaczenie dla przemian miała nowela konstytucyjna z grudnia 1989 r. Nastapiło wówczas odejście od idei konstytucji państwa totalitarnego. Wprowadzono jako podstawy ustroju zasadę demokratycznego państwa prawnego, niezależnego samorządu terytorialnego i zagwarantowano swobodę działalności gospodarczej 
bez względu na formę własności (jej ograniczenie mogło następować jedynie w ustawie). Zniesiono także instytucję narodowego planu społeczno-gospodarczego charakterystycznego dla gospodarki socjalistycznej.

Kolejna zmiana dokonała się na mocy Małej Konstytucji z 1992 r. Ustawa konstytucyjna wprowadziła ochronę przysługujących jednostce samorządu terytorialnego prawa własności i innych praw majątkowych stanowiaccych mienie komunalne. Zachowano przy tym w mocy przepisy dotyczace praw jednostki wprowadzone nowela grudniowa.

Ostatecznie w Konstytucji z 1997 r. w sposób całościowy uregulowano ustrój polityczny, gospodarczy i społeczny państwa. W art. 20 statuowano zasadę społecznej gospodarki rynkowej, kolejne przepisy zawarte w art. 21-23 stanowią o ochronie własności, wolności gospodarczej i uznają gospodarstwo rodzinne za podstawę ustroju rolnego państwa. Jako prawa jednostki (ustrojodawca posługuje się terminem „każdy”) wskazane są prawo własności i inne prawa majątkowe z art. 64. Ważna z punktu widzenia gospodarki jest także klauzula europejska (art. 90), wskutek zawarcia traktatu akcesyjnego stworzone bowiem zostały podstawy prawne swobody przepływu kapitału, usług i pracy, a także zasada pierwszeństwa umów ratyfikowanych za zgodą wyrażoną w ustawie (art. 89). Zasada ta odnosi się również do umów dwustronnych o ochronie inwestycji, które stymulują napływ inwestycji zagranicznych.

Ustrojodawca wśród zasad ogólnych dotyczących wolności i praw wyróżnił w art. 31 zasadę proporcjonalności (stosowaną już wcześniej przez Trybunał Konstytucyjny wzorem innych sądów konstytucyjnych).

Zapisanie w Konstytucji pojęcia społecznej gospodarki rynkowej (art. 20) było usankcjonowaniem wprowadzenia do systemu prawnego, po 1989 r., ochrony własności prywatnej i wolności gospodarczej. Konstytucja, określając ustrój państwa, stanowi tym samym także o systemie gospodarczym i społecznym - w pierwszej kolejności stanowią o tym zasady ustrojowe wymienione w rozdziale I. Na nich zaś oparte są dalsze regulacje konstytucyjne. Zasadnicze cele, które wynikają z mającego podstawowe znaczenie art. 20, to wolność gospodarowania i sprawiedliwość społeczna. Społeczna gospodarka rynkowa oznacza bowiem związanie rynku z odpowiedzialnością społeczna. Artykuł 20 ma charakter programowy i jest dyrektywą wiążącą zarówno ustawodawcę, jak i władzę wykonawczą. Zasada społecznej gospodarki rynkowej znajduje wyraz w wolności gospodarczej, własności prywatnej, solidarności i współpracy partnerów społecznych.

Regulacja konstytucyjna ogranicza jednocześnie ustawodawcę w kształtowaniu zasad gospodarowania - granicami są przysługujące jednostce wolności i prawo własności. Wynikają one także z zasady proporcjonalności zapisanej w art. 31 ust. 3 Konstytucji. Jest ona szczególnie ważna ze względu na to, że Ustawa zasadnicza odwołuje się często do określenia zasad realizacji wolności i praw w drodze ustawy. Oznacza to możliwość wprowadzania ustawą ograniczeń wolności lub prawa. Ograniczenia te podlegają więc ocenie w kontekście zasady proporcjonalności. O ich dopuszczalności rozstrzyga ostatecznie Trybunał Konstytucyjny. 
Wolność działalności gospodarczej jest zasadą ustrojową. Organy państwa mają więc obowiązek tworzyć warunki służące realizacji wolności, której gwarancją jest własność prywatna, a także wolność wyboru i wykonywania zawodu i wyboru miejsca pracy (art. 65). W gospodarce rynkowej niezbędna jest własność prywatna środków produkcji. Zagwarantowanie prywatnych środków produkcji w art. 21 ust. 1 Konstytucji służy ochronie jednego z podstawowych praw człowieka oraz umożliwia racjonalność decyzji gospodarczych.

W Konstytucji z 1997 r. wyróżniona jest własność prywatna i publiczna. Nie została przy tym wskazana wprost własność państwowa. Prawo własności (własność komunalna - art. 165 ust. 1) przysługujące jednostkom samorządu terytorialnego determinuje jego ustrój. Samodzielne dysponowanie przez samorząd terytorialny własnością decyduje o możliwości realizacji zadań publicznych, dlatego też tak istotne jest umocowanie własności komunalnej wprost w Konstytucji.

Niewątpliwie wprowadzenie do Konstytucji ochrony własności prywatnej i komunalnej, a także wolności gospodarczej, daje szczególnie silny tytuł tym prawom i wolności. Ustawodawca nie może bowiem nie tylko ich pozbawić, ale także naruszyć istoty prawa lub wolności.

Przepisy rozdziału I Konstytucji zawarte w art. 20 i art. 21 sankcjonuja zmiany systemu prawnego dokonane po 1989 r., których wyrazem jest zniesienie ograniczeń prawa własności i zrównanie rodzajów własności. Niewątpliwie ochrona własności ustanowiona w Konstytucji daje jej silniejsze umocowanie niż ochrona wynikająca wyłącznie z ustawy. Należy przy tym pamiętać, że Konstytucja dopuszcza ograniczenie wolności gospodarczej i prawa własności. Oznacza to, że nie mają one charakteru absolutnego i w określonych sytuacjach ustępują innym prawom lub interesowi publicznemu. Zawsze przy tym ustawodawca ważyć musi wartości konstytucyjne przemawiające za wprowadzeniem ograniczeń w drodze ustawy.

Barierą konstytucyjną chroniąca przed nadmierną gorliwością prawodawcy we wkraczaniu w sferę wolności gospodarczej i własność jest konieczność przestrzegania przez ustawodawcę zasad wynikających z art. 2 i art. 31 ust. 3 Konstytucji. Chodzi o nakaz tworzenia prawa zgodnie z zasadami przyzwoitej legislacji oraz dopuszczalność wprowadzania ograniczeń wolności i praw jedynie wtedy, gdy jest to konieczne w państwie demokratycznym (w ramach wskazanych wprost w Konstytucji wartości), a ograniczenia, najogólniej rzecz ujmujacc, są odpowiednie do zamierzonego celu i najmniej uciążliwe spośród możliwych do zastosowania. Wynika z tego obowiązek tworzenia prawa, które nie będzie zawierało ograniczeń wolności innych niż te, które sa absolutnie niezbędne. Ta właśnie dyrektywa powinna być w każdym przypadku brana pod uwagę nie tylko w parlamencie, lecz także już na poziomie planowania prac legislacyjnych. Ostatecznie zasada proporcjonalności stanowi o konieczności ważenia przez sąd konstytucyjny racji przemawiających za wprowadzeniem konkretnych ograniczeń wolności gospodarczej lub własności.

Należy przy tym podkreślić, że wolność gospodarcza realizowana jest poprzez ustawy uchwalane przez Sejm. Stopień wolności gospodarczej zależy od skali reglamentacji. Jak podnosi doktryna, po 1989 r. wystapiły zaskakujace 
tendencje ustawowego ograniczania wolności gospodarczej ${ }^{1}$. W porównaniu z ustawą z 23 grudnia 1988 r. o działalności gospodarczej², widoczne było rozszerzanie zakresu reglamentacji. Ograniczenie ingerencji w wolność gospodarowania nastapiło w ustawie z 19 listopada 1999 r. - Prawo działalności gospodarczej ${ }^{3}$, a kolejna taka interwencja ustawodawcy miała miejsce w 2004 r. (ustawa z 2 lipca 2004 r. o swobodzie działalności gospodarczej). Dodać przy tym należy, że w niektórych przypadkach obowiązek reglamentacji działalności gospodarczej wynika z prawa Unii Europejskiej (które nie wskazuje przy tym jego form). Niezależnie od zakresu działalności reglamentowanej istotna jest forma, w jakiej reglamentacja ta następuje. Zależy bowiem od tego zakres uznania organu administracji (wymóg koncesji uznania lub zezwolenia). Kwestie te niewątpliwie istotnie wiążą się z granicami ingerencji w sferę przedsiębiorczości wyprowadzanymi z art. 31 ust. 3 Konstytucji. Dyrektywy wynikajace z art. 31 ust. 3 Konstytucji powinny być więc ważnym punktem odniesienia dla ustawodawcy przy wprowadzaniu ograniczeń wolności gospodarczej.

Nowe uwarunkowania ustrojowe, usankcjonowane w Konstytucji z 1997 r., spowodowały powstanie szczegółowych regulacji dotyczaccych danin publicznych. Mimo że nakładanie lub zwiększanie danin publicznych powoduje uszczuplenie własności, takie działanie ustawodawcy nie jest uznawane w orzecznictwie Trybunału Konstytucyjnego za naruszenie własności. Nie oznacza to jednak braku granic nakładanych podatków i innych ciężarów publicznych. Nie mogą one naruszać istoty konstytucyjnej wolności lub prawa.

Jednocześnie nowe uwarunkowania ustrojowe wymusiły też z miany systemu podatkowego. Jednym z najistotniejszych celów zapoczątkowanej w 1989 r. transformacji ustrojowej było zrównanie wszystkich sektorów własnościowych gospodarki przez zniesienie kategorii jednostek gospodarki uspołecznionej i odejście od zasady szczególnej ochrony własności społecznej. Osiagnięcie tego celu nie byłoby jednak możliwa bez kluczowych zmian w systemie podatkowym. Konieczne stało się m.in. wprowadzenie jednolitego opodatkowania działalności gospodarczej niezależnie od sektora własnościowego oraz formy prawnej prowadzenia tej działalności, oczywiście z uwzględnieniem specyfiki opodatkowania osób fizycznych i prawnych, a także ujednolicenie zasad opodatkowania konsumpcji ${ }^{5}$. Wzorcem przeprowadzonej w Polsce reformy podatkowej była konstrukcja systemów podatkowych w krajach o gospodarce rynkowej.

1 Szerzej C. Kosikowski, Zasady ustroju społecznego $i$ gospodarczego $w$ procesie stosowania Konstytucji, Warszawa 2005, s. 55 i 56.

${ }^{2}$ Dz. U. Nr 41, poz. 324 ze zm.

${ }^{3}$ Dz. U. Nr 101, poz. 1178 ze zm.

${ }^{4}$ Dz. U. Nr 173, poz. 1807 ze zm.

5 Szerzej na temat założeń reformy zob. I. Bolkowiak, Polski system podatkowy w okresie transformacji ustrojowej (lata 1989-1996), Warszawa 1998, s. 16; J. Fiszer, Reforma podatkowa $w$ Polsce, Warszawa 1991, s. 12 i n.; Zamierzenia rzadu w realizacji planu konsolidacji gospodarki narodowej i budżetu państwa na rok 1989, „Finanse” 1989, nr 1, s. 3-5. 
W odniesieniu do opodatkowania dochodów osób fizycznych od 1 stycznia 1992 r. wprowadzono powszechny podatek dochodowy od osób fizycznych ${ }^{6}$, który zastapił pięć podatków związanych z uzyskiwaniem przez osoby fizyczne różnego rodzaju dochodów. Zasadnicze zmiany w opodatkowaniu osób prawnych nastapiły w latach 1989-1992. Ustawą z 1989 r. wprowadzono jednolite opodatkowanie dochodów wszystkich osób prawnych, niezależnie od ich przynależności do sektora własnościowego ${ }^{7}$. Uchwalenie drugiej, obowiazującej do dzisiejszego dnia, ustawy o podatku dochodowym od osób prawnych z 1992 r. było związane z wprowadzeniem powszechnego podatku dochodowego od osób fizycznych i potrzebą względnego ujednolicenia zasad opodatkowania dochodów osób fizycznych i prawnych, pochodzacych z tych samych źródeł przychodów ${ }^{8}$. Dla opodatkowania konsumpcji zasadnicze znaczenie miało wprowadzenie podatku od towarów i usług, a także uzupełniającego go podatku akcyzowego ${ }^{9}$.

Przebudowa państwa oznaczała, jak już wspomniano, także reaktywację samorządu terytorialnego, wyrazem przyjętej zasady decentralizacji było zaś przyznanie gminom atrybutu niezależności, w tym niezależności majątkowej i finansowej. Niezależność majątkowa znalazła wyraz w procesie komunalizacji części mienia publicznego, natomiast niezależność finansowa wiązała się z konstytucyjnie zagwarantowanym prawem do uchwalania własnych budżetów oraz stworzeniem systemu finansowania jednostek samorządu. Przywrócony samorząd terytorialny musiał zostać wyposażony w odrębne źródła dochodów, w tym także o charakterze podatkowym ${ }^{10}$.

W literaturze przedmiotu rok 1989 postrzegany jest zgodnie jako początek związanej z transformacją ustrojową reformy polskiego systemu podatkowego.

\section{PRYWATYZACJA}

Jednym z założeń zmiany systemu gospodarczego było przekonanie o konieczności dokonania prywatyzacji podmiotów tworzących polską gospodarkę, a więc przede wszystkim przedsiębiorstw państwowych.

Podstawowym aktem prawnym regulującym procesy prywatyzacji w pierwszej połowie lat dziewięćdziesiątych była ustawa z 13 lipca $1990 \mathrm{r}$. o prywatyzacji przedsiębiorstw państwowych ${ }^{11}$. Na jej podstawie, jak również

${ }^{6}$ Ustawa z 26 lipca 1991 r. o podatku dochodowym od osób fizycznych, t.jedn.: Dz. U. 2012, poz. 361 ze zm.

${ }^{7}$ Ustawa z 31 stycznia 1989 r. o podatku dochodowym od osób prawnych, t.jedn.: Dz. U. 1991, Nr 49, poz. 216 ze zm.

${ }^{8}$ Ustawa z 15 lutego 1992 r. o podatku dochodowym od osób prawnych, t.jedn.: Dz. U. 2011, Nr 74, poz. 397 ze zm.

${ }^{9}$ Ustawa z 8 stycznia 1993 r. o podatku od towarów i usług oraz o podatku akcyzowym, Dz. U. Nr 11, poz. 50 ze zm.

${ }^{10}$ Ustawa z 14 grudnia 1990 r. o dochodach gmin i zasadach ich subwencjonowania w latach 1991-1993 oraz o zmianie ustawy o samorządzie terytorialnym, Dz. U. Nr 89, poz. 518 ze zm.

${ }^{11}$ Dz. U. Nr 51, poz. 298 ze zm. 
na podstawie ustawy z 30 kwietnia 1993 r. o narodowych funduszach inwestycyjnych i ich prywatyzacji ${ }^{12}$, a także ustawy z 3 lutego 1993 r. o restrukturyzacji finansowej przedsiębiorstw i banków oraz o zmianie niektórych ustaw ${ }^{13}$, wykształciły się trzy typy przekształceń własnościowych:

1. Przekształcenia w drodze kapitałowej (prywatyzacja pośrednia).

2. Przekształcenia w drodze likwidacyjnej (prywatyzacja bezpośrednia).

3. Przekształcenia w drodze powszechnej prywatyzacji w ramach programu Narodowych Funduszy Inwestycyjnych (NFI).

Powyżej wspomnianą ustawą z 13 lipca 1990 r. o prywatyzacji przedsiębiorstw państwowych wprowadzono możliwość oraz określono zasady przekształcania przedsiębiorstw państwowych w jednoosobowe spółki Skarbu Państwa oraz udostępniania akcji lub udziałów w tych spółkach, jak również udostępniania mienia przedsiębiorstwa lub jego sprzedaży. Zgodnie z ta ustawą przed zainicjowaniem procesu prywatyzacji pośredniej przedsiębiorstwa państwowego musiało zostać przeprowadzone przekształcenie przedsiębiorstwa państwowego w jednoosobową spółkę (akcyjną albo z ograniczoną odpowiedzialnościa) Skarbu Państwa, tj. komercjalizacja. W myśl ustawy przekształcenia przedsiębiorstw państwowych w spółki dokonywał minister przekształceń własnościowych na wniosek organu założycielskiego, dyrektora przedsiębiorstwa państwowego i rady pracowniczej lub prezes Rady Ministrów na wniosek ministra przekształceń własnościowych. W spółce powstałej w wyniku komercjalizacji, do czasu sfinalizowania jej prywatyzacji, Skarb Państwa obejmował 100\% akcji lub udziałów. Do spółek powstałych w wyniku przekształcenia przedsiębiorstw państwowych generalnie stosowano przepisy Kodeksu handlowego, z zastrzeżeniami wynikającymi z ustawy (np. w odniesieniu do zasad rachunkowości). Przekształcenie przedsiębiorstw państwowych w spółki miało na celu umożliwienie zbywania akcji tak powstałych spółek. Zgodnie z ustawą przed zaoferowaniem zbycia akcji lub udziałów spółki Skarbu Państwa zarządzano przeprowadzenie analizy ekonomiczno-finansowej spółki w celu ustalenia jej wartości oraz analizy prawnej, celem ustalenia stanu prawnego majątku spółki, ze szczególnym uwzględnieniem roszczeń osób trzecich do tego majątku. Nie bez znaczenia jest bowiem fakt, że w tym czasie już zaczęły się pojawiać roszczenia, wynikające z często nieuregulowanych z powodu zaniedbania kwestii własnościowych, szczególnie związanych ze statusem własnościowym nieruchomości. Akcje należące do Skarbu Państwa w spółkach powstałych w wyniku przekształcenia przedsiębiorstw państwowych mogły być zbywane w trybie przetargu publicznego, na podstawie oferty ogłoszonej publicznie lub w wyniku rokowań podjętych na podstawie publicznego zaproszenia. Ustawa przewidywała ponadto prawo zakupu przez pracowników przekształconego przedsiębiorstwa państwowego na zasadach preferencyjnych do 20\% akcji Skarbu Państwa w spółce powstałej z przedsiębiorstwa państwowego.

Ustawa wprowadzała również model prywatyzacji bezpośredniej w drodze likwidacji przedsiębiorstw państwowych. Prywatyzacja bezpośrednia była

12 Dz. U. Nr 44, poz. 202 ze zm.

13 Dz. U. Nr 18, poz. 82 ze zm. 
realizowana bez przyjmowania przez przedsiębiorstwo państwowe formy organizacyjno-prawnej w postaci jednoosobowej spółki Skarbu Państwa. Model ten miał na celu umożliwienie dokonywania szybkich zmian własnościowych w przedsiębiorstwach państwowych, głównie małych i średnich. Zgodnie z ustawą organ założycielski, za zgodą ministra przekształceń własnościowych, mógł zlikwidować przedsiębiorstwo państwowe w celu: sprzedaży przedsiębiorstwa lub zorganizowanych części mienia przedsiębiorstwa, wniesienia przedsiębiorstwa lub zorganizowanych części mienia do spółki oraz oddania na czas oznaczony do odpłatnego korzystania przedsiębiorstwa lub zorganizowanych części mienia przedsiębiorstwa.

Dodatkowo, na mocy wyżej wspomnianej ustawy z 3 lutego 1993 r. o restrukturyzacji finansowej przedsiębiorstw i banków oraz o zmianie niektórych ustaw, wprowadzono regulacje dotyczące możliwości zamiany wierzytelności wobec przedsiębiorstw państwowych lub jednoosobowych spółek Skarbu Państwa na akcje. Oczywiście w przypadku wierzytelności wobec przedsiębiorstw państwowych zamiana tych wierzytelności musiała być poprzedzona przekształceniem przedsiębiorstwa państwowego w jednoosobową spółkę Skarbu Państwa.

Po kilku latach doświadczeń w prywatyzacji opartej na przepisach ustawy z 13 lipca 1990 r., w 1996 r. weszła w życie ustawa o komercjalizacji i prywatyzacji przedsiębiorstw państwowych ${ }^{14}$. Jej podstawowe rozwiązania stanowiły kontynuacje poprzedniej ustawy. Nowa ustawa wprowadziła oczywiście bardziej precyzyjne opisy procesów przekształcania przedsiębiorstw (określonych już wprost w ustawie jako komercjalizacja) czy przeprowadzania prywatyzacji (określonej już wprost w ustawie jako prywatyzacja pośrednia i bezpośrednia), jak również wprowadziła nową terminologię, zachowując jednak podstawowe zasady dokonywania przekształceń przedsiębiorstw oraz ich prywatyzacji.

Można przy tym wskazać, że prywatyzacja bezpośrednia, zgodnie z nowa ustawa, nie była już określana jako likwidacja przedsiębiorstwa, a jako rozporządzenie wszystkimi składnikami materialnymi i niematerialnymi majątku przedsiębiorstwa państwowego.

Należy pamiętać, że niestety regulacje te są wytworem kompromisu między tymi, którzy chcieli prywatyzować, a tymi, dla których ideałem była nadal gospodarka społeczna. Miłośnicy gospodarki uspołecznionej, wraz z węszącymi wszędzie przestępstwo przeciwnikami prywatyzacji, wielokrotnie doprowadzali do spowolnienia procesów przekształceń własnościowych. Przy prywatyzacji bezpośredniej te ataki były stosunkowo mniej spektakularne, być może z tego względu, że jedną z form prywatyzacji bezpośredniej jest założenie spółki pracowniczej, a więc znowu pewnej mutacji społecznej formuły własności. Na pewno jednak efekt prywatyzacji bezpośredniej dla wielu osób okazał się zbawienny, ponieważ m.in. utrzymały swe miejsca pracy.

Metoda tzw. prywatyzacji pośredniej, inaczej zwanej kapitałowa, była natomiast stosowana w przypadku dużych podmiotów gospodarczych. Dokonywano tego w różny sposób. W niektórych sytuacjach akcje spółek zostały udostępnione w ofercie publicznej. W innych dla zbycia pierwszego pakietu akcji

\footnotetext{
14 Dz. U. Nr 118, poz. 561 ze zm.
} 
bądź udziałów zastosowano formę przetargu publicznego. W największej liczbie podmiotów zastosowano tryb publicznego zaproszenia do rokowań. Były też przypadki stosowania podwójnych transakcji, tj. zbycia akcji w ofercie publicznej oraz sprzedaży ich inwestorowi strategicznemu. Można tu wspomnieć, że w 2006 r. wprowadzono możliwość zbywania akcji należących do Skarbu Państwa w trybie aukcji ogłaszanej publicznie. W tym trybie wielu inwestorów zagranicznych dokonało zakupu akcji czy udziałów spółek. Różnorodność inwestorów nie potwierdza tezy głoszonej tu i ówdzie przez różnych polityków, że oto ta czy inna nacja wykupiły już niemal całą Polskę.

$\mathrm{W}$ procesie prywatyzacji kapitałowej bardzo istotna kwestia jest tzw. pakiet inwestorski. Oznacza to, że na rozwój spółek funkcjonujących w Polsce, w których pracują Polacy, zobowiązano się przeznaczyć stosowne i wcale niebagatelne kwoty.

Generalnie należy wskazać, że pomimo niedoskonałości, zarówno w sferze prawnej, jak i w sposobie realizacji przepisów, dotyczących prywatyzacji przedsiębiorstw państwowych, skutkiem przeprowadzonych przekształceń jest powstanie wielu podmiotów mogących prowadzić działalność na zasadach konkurencji w nowoczesnej gospodarce rynkowej. Powstały bowiem podmioty posiadające określoną własność i mające określoną strukturę właścicielską.

\section{NARODOWE FUNDUSZE INWESTYCYJNE}

Jednym z elementów przeprowadzenia w Polsce prywatyzacji majątku państwowego był Program Powszechnej Prywatyzacji (PPP), który zakładał przekształcenie 512 przedsiębiorstw państwowych w spółki akcyjne. Program ten miał na celu przekształcenie dotychczasowej, nieefektywnej formuły prowadzenia działalności w formie przedsiębiorstw państwowych w nowa, prowadzoną w formie podmiotów prawa handlowego. Miało to umożliwić przekształconym podmiotom dostęp do kapitału oraz nowych technologii i know-how, jak również poszerzyć ich możliwości konkurowania na nowych rynkach zbytu. Elementem tego Programu było utworzenie Narodowych Funduszy Inwestycyjnych na mocy wyżej wspomnianej ustawy z 30 kwietnia 1993 r. o narodowych funduszach inwestycyjnych i ich prywatyzacji. Utworzonych zostało 15 Funduszy działających w formie spółek akcyjnych, do których Skarb Państwa wniósł akcje sprywatyzowanych byłych przedsiębiorstw państwowych. Narodowe Fundusze Inwestycyjne miały się zajmować restrukturyzacją spółek utworzonych z dawnych przedsiębiorstw państwowych, w celu umożliwienia ich funkcjonowania w nowych realiach gospodarczych. Program opierał się na założeniu, że każdy z obywateli dzięki nabyciu świadectwa udziałowego będzie posiadał część majątku państwowego. Miało to więc być powszechne uwłaszczenie społeczeństwa na majątku Skarbu Państwa w trakcie transformacji ustrojowej dzięki przekazaniu wszystkim uprawnionym obywatelom cząstki majątku w postaci akcji funduszy. Zgodnie z Programem wszyscy pełnoletni obywatele polscy byli uprawnieni do nabycia powszechnych świadectw udzia- 
łowych, które można było następnie zbyć lub wymienić na akcje Narodowych Funduszy Inwestycyjnych.

Jednym z zasadniczych celów, jakie stawiano przed programem NFI, miało być rozproszenie majątku i upowszechnienie własności kapitału w polskim społeczeństwie, co w efekcie przyczyniłoby się do powstania tzw. klasy średniej, a tym samym większej akceptacji społecznej zachodzących procesów transformacji systemowej. Program ten jednak miał i ujemne strony.

Firmy zarządzające NFI często nie wypełniały swojego podstawowego obowiąku, czyli nie sprawowały odpowiedniego nadzoru właścicielskiego nad wniesionymi do Funduszy spółkami i nie potrafiły znaleźć dla nich odpowiedniej strategii inwestycyjnej. Efektem niewłaściwego zarządzania było więc, w wielu przypadkach, pogorszenie sytuacji ekonomicznej zarządzanych spółek. Ponadto NFI rzadko podejmowały działania zmierzające do poprawy sytuacji w zarządzanych spółkach, a ich strategia sprowadzała się często jedynie do działań zmierzajacych do sprzedaży zarządzanych podmiotów.

Ostatecznie Program ten zakończył swój byt z dniem 31 grudnia 2012 r. na mocy ustawy z 30 marca 2012 r. o uchyleniu ustawy o narodowych funduszach inwestycyjnych i ich prywatyzacji oraz o zmianie niektórych innych ustaw ${ }^{15}$.

Prywatyzacja przyciagnęła też kapitał zagraniczny. Napływ kapitału zagranicznego do Polski można obserwować od początku okresu transformacji, chociaż rozwiązania ustawowe dotyczace podejmowania i prowadzenia działalności gospodarczej z udziałem podmiotów zagranicznych pojawiły się już wcześniej - np. obowiązująca od dnia 1 stycznia 1989 r. ustawa o działalności gospodarczej z udziałem podmiotów zagranicznych ${ }^{16}$, która znosiła ograniczenie własności w spółkach, dopuszczając w 100\% własność zagraniczną.

Po zmianie systemu gospodarczego rozpoczęto dostosowywanie obowiąującego prawa do zasad gospodarki rynkowej i pełniejszego otwarcia na kapitał zagraniczny. Ustawa z 14 czerwca 1991 r. o spółkach z udziałem zagranicznym $^{17}$ znosiła wiele ograniczeń dla inwestorów zagranicznych, jednak nie dawała jeszcze pełnej swobody działania we wszystkich dziedzinach gospodarki. Znaczaca zmiana zasad określonych tą ustawą została dokonana na mocy jej nowelizacji z 29 marca $1996 \mathrm{r}^{18}{ }^{18}$ zniesiono m.in. ograniczenia w uzyskiwaniu zezwoleń na działalność w branżach chronionych dotychczas przez państwo. Kolejne regulacje ustawowe wprowadzały w Polsce rozwiązania pozostajace w zgodzie z głównymi zasadami światowej gospodarki rynkowej, co pozwalało na stworzenie znacząco lepszych możliwości inwestowania przez podmioty zagraniczne. Można tu wskazać na ustawę z 19 listopada 1999 r. - Prawo działalności gospodarczej, ustawę z 20 marca 2002 r. o finansowym wspieraniu inwestycji ${ }^{19}$ czy ustawę z 2 lipca 2004 r. o swobodzie działalności gospodarczej. Nie bez znaczenia pozostawało również stopniowe dokonanie zasadniczego

15 Dz. U. 2012, poz. 596.

16 Ustawa z 23 grudnia 1988 r. o działalności gospodarczej z udziałem podmiotów zagranicznych, Dz. U. Nr 41, poz. 325 ze zm.

17 Dz. U. Nr 60, poz. 253 ze zm.

18 Ustawa z 29 marca 1996 r. o zmianie ustawy o spółkach z udziałem zagranicznym, Dz. U. Nr 45, poz.199 ze zm.

19 Dz. U. Nr 41, poz. 363 ze zm. 
przemodelowania regulacji związanych z prowadzeniem gospodarki finansowej - w szczególności zmiany ustaw podatkowych (o czym była mowa wyżej), prawa dewizowego czy prawa bankowego. Istotnym elementem umożliwiającym rozwój działalności przez inwestorów zagranicznych w Polsce było również rozpoczęcie funkcjonowania rynku kapitałowego, w szczególności wprowadzenie ustawą z 22 marca 1991 r. regulacji dotyczących publicznego obrotu papierami wartościowymi i funduszy powierniczych ${ }^{20}$.

Równie ważne było szybkie włączanie się Polski do porozumień międzynarodowych. Na poziomie bilateralnym realizuje się to przez zawieranie międzynarodowych umów dwustronnych o znoszeniu podwójnego opodatkowania oraz ochronie i popieraniu wzajemnych inwestycji. Na poziomie ogólnoeuropejskim istotne było zawarcie 16 grudnia $1991 \mathrm{r}$. Układu o stowarzyszeniu z Unią Europejska, co miało na celu umożliwienie przygotowania Polski do członkostwa w Unii Europejskiej. Równocześnie niejako wymusiło to na Polsce konieczność stopniowego dostosowywania ustawodawstwa wewnętrznego do zasad obowiązujących w państwach członkowskich UE. Stwarzało to z kolei gwarancje instytucjonalne i prawne dla inwestorów zagranicznych, dające im większą pewność i przewidywalność prowadzenia działalności w naszym kraju.

Kapitał zagraniczny stwarza $\mathrm{w}$ gospodarce nowe możliwości, związane m.in. ze wzrostem produkcji, zatrudnienia i zwiększeniem eksportu. Ponadto napływ kapitału zagranicznego przyczynił się znacząco do postępu technicznego, wprowadzając innowacyjne rozwiązania, nowe technologie, know-how i sposoby zarządzania. Wszystko to stworzyło większe możliwości dostępu do nowych rynków, podnosząc tym samym konkurencyjność polskiej gospodarki.

\section{PRZEZNACZENIE ŚRODKÓW Z PRYWATYZACJI}

Zgodnie z ustawą z 27 sierpnia 2009 r. o finansach publicznych ${ }^{21}$ przychody z prywatyzacji majątku Skarbu Państwa stanowią jedno ze źródeł finansowania deficytu budżetu państwa oraz innych jego potrzeb pożyczkowych.

Zgodnie $\mathrm{z}$ art. 56 obecnie obowiązującej ustawy o komercjalizacji i prywatyzacji, z przychodów uzyskanych z prywatyzacji tworzy się następujące państwowe fundusze celowe:

- Fundusz Reprywatyzacji z przeznaczeniem na cele związane z zaspokajaniem roszczeń byłych właścicieli mienia przejętego przez Skarb Państwa, tj. na wypłatę odszkodowań;

- Fundusz Restrukturyzacji Przedsiębiorców z przeznaczeniem na pomoc w celu ratowania lub restrukturyzacji przedsiębiorców oraz na udzielanie wsparcia niebędącego pomocą publiczną;

${ }^{20}$ Ustawa z 22 marca 1991 r. - Prawo o publicznym obrocie papierami wartościowymi i funduszach powierniczych, Dz. U. Nr 35, poz. 155 ze zm.

${ }^{21}$ T.jedn.: Dz. U. 2013, poz. 885 ze zm. 
- Fundusz Skarbu Państwa na pokrycie kosztów prywatyzacji, gospodarowania mieniem Skarbu Państwa, uzupełnienie środków brakujacych na pokrycie kosztów procesów likwidacyjnych i postępowania upadłościowego czy podwyższenie kapitału zakładowego spółek z udziałem Skarbu Państwa;

- Fundusz Nauki i Technologii Polskiej z przeznaczeniem na cele zwiazane z rozwojem nauki i technologii polskiej, obejmujace wspieranie szczególnie ważnych kierunków badań naukowych lub prac rozwojowych określanych w założeniach polityki naukowo-technicznej państwa, wspieranie inwestycji służących potrzebom badań naukowych lub prac rozwojowych oraz promocję i upowszechnianie nauki.

Ponadto środki z prywatyzacji sa przeznaczane na sfinansowanie wzrostu aktywów finansowych gromadzonych w Funduszu Rezerwy Demograficznej zarządzanym przez ZUS, zgodnie z ustawą z 9 stycznia 2009 r. o zmianie ustawy o systemie ubezpieczeń społecznych ${ }^{22}$, czy zaspokojenie roszczeń z tytułu zaciagniętego długu wynikającego z udzielonych przez Skarb Państwa poręczeń i gwarancji, zgodnie z ustawą z 22 stycznia 2010 r. o zmianie ustawy o poręczeniach i gwarancjach udzielanych przez Skarb Państwa oraz niektóre osoby prawne oraz ustawy o komercjalizacji i prywatyzacji ${ }^{23}$.

\section{UWŁASZCZENIE OSÓB PRAWNYCH}

Jednym z elementów uporządkowania systemu własnościowego w odniesieniu do mienia państwowego było wprowadzenie regulacji dotyczących określenia statusu mienia pozostającego przed rokiem 1990 w zarządzie państwowych i komunalnych osób prawnych.

Regulacje dotyczące uwłaszczenia osób prawnych zostały wprowadzone ustawą z 29 września 1990 r. o zmianie ustawy o gospodarce gruntami i wywłaszczaniu nieruchomości ${ }^{24}$. Ustawa ta przewidywała, że grunty stanowiace własność Skarbu Państwa lub własność gminy będące w dniu wejścia w życie w zarządzie państwowych osób prawnych innych niż Skarb Państwa stają się z tym dniem, z mocy prawa, przedmiotem użytkowania wieczystego. Natomiast budynki i inne urządzenia oraz lokale znajdujące się na tych gruntach będących w dniu wejścia w życie ustawy w zarządzie osób prawnych zgodnie z ustawą stały się z tym dniem, z mocy prawa, własnością tych osób.

Regulacje prawne dotyczące uwłaszczenia państwowych osób prawnych zostały utrzymane i obecnie sa zawarte w ustawie z 21 sierpnia 1997 r. o gospodarce nieruchomościami ${ }^{25}$. Tak więc uwłaszczenie osób prawnych w stosunku do nieruchomości trwa nadal i można porównać tę instytucję do komunalizacji

\footnotetext{
${ }^{22}$ Dz. U. Nr 14, poz. 75.

23 Dz. U. Nr 28, poz. 144.

${ }^{24}$ Dz. U. Nr 79, poz. 464.

25 Dz. U. Nr 115, poz. 741 ze zm.
} 
mienia państwowego. Należy przy tym uznać, że wprowadzenie takich regulacji było niezbędne, gdyż pozwoliło na podjęcie próby uporządkowania statusu wielu składników dotychczasowego mienia państwowego, co z kolei umożliwiło dokonanie procesów prywatyzacyjnych i innych przekształceń własnościowych.

\section{KOMUNALIZACJA}

Jednym z istotnych elementów tworzenia nowych zasad gospodarowania dotychczasowym mieniem państwowym było wprowadzenie regulacji dotyczących komunalizacji majątku państwowego. Było to związane z wprowadzeniem w 1990 r. nowego sposobu organizacji samorządu terytorialnego przez utworzenie samodzielnych jednostek terytorialnych podejmujących decyzje w imieniu własnym i na własną odpowiedzialność. W dniu 27 maja 1990 r. wprowadzono bowiem w Polsce nowy ustrój gmin na mocy tzw. ustaw samorządowych: ustawy z 8 marca 1990 r. o samorządzie terytorialnym ${ }^{26}$ oraz ustawy z 10 maja 1990 r. - Przepisy wprowadzające ustawę o samorządzie terytorialnym i ustawę o pracownikach samorządowych ${ }^{27}$. Przyznano więc jednostkom samorządu uprawnienie stanowienia prawa miejscowego i wykonywanie olbrzymiej większości zadań z zakresu administracji lokalnej czy też regionalnej. Wychodzono bowiem z założenia, że sprawowanie władzy publicznej powinno spoczywać w rękach instytucji najbliższych zainteresowanym obywatelom.

Gminy stały się podmiotami publicznoprawnymi, uzyskując prawo do posiadania majątku. Aby umożliwić sprawne wykonywanie zadań nałożonych na jednostki samorządu terytorialnego, niezbędne było przekazanie tym jednostkom mienia, którym mogłyby one gospodarować. Dokonywało się to przede wszystkim w drodze komunalizacji mienia państwowego.

Zgodnie ze wspomnianą ustawą z 10 maja 1990 r. dotychczasowe mienie państwowe należące do rad narodowych oraz terenowych organów państwowych stopnia podstawowego, jak również mienie przedsiębiorstw państwowych, dla których powyższe jednostki były organami założycielskimi, oraz mienie zakładów i innych jednostek organizacyjnych podporządkowanych powyższym organom stało się z mocy prawa mieniem właściwych gmin. Dodatkowo ustawa przewidywała możliwość przekazania gminom innego mienia państwowego, o ile było ono związane z realizacją ich zadań. Ponadto przedsiębiorstwa państwowe, dla których funkcję organu założycielskiego pełniły terenowe organy administracji państwowej, stały się przedsiębiorstwami komunalnymi. Nabycie mienia na podstawie powyższej ustawy następowało nieodpłatnie. Ustawa określiła także, że fakt nabycia mienia przez gminę zostaje potwierdzony w drodze decyzji wydawanych przez wojewodów.

W intencji twórców regulacji komunalizacja miała doprowadzić do bardzo szybkiego przejęcia majątku państwowego przez nowo powołane struktury

26 Dz. U. Nr 16, poz. 95 ze zm.

27 Dz. U. Nr 32, poz. 191 ze zm. 
samorządu terytorialnego. Generalny cel wynikający z nowego kształtu organizacji państwa został osiagnięty, niemniej proces komunalizacji okazał się w praktyce dużo bardziej skomplikowany. Wynikało to z faktu wieloletnich zaniedbań w regulowaniu stanów prawnych nieruchomości. Przed rokiem 1989 powszechne było bowiem przeświadczenie (skądinąd wynikające z obowiązujących regulacji prawnych), że całe mienie stanowi mienie państwowe, co powodowało brak dbałości o formalne uregulowanie statusu poszczególnych składników majątkowych. Skutkiem takiego stanu jest trwający do dziś dzień (a więc blisko 25 lat) proces potwierdzania faktu skomunalizowania poszczególnych składników mienia państwowego, przede wszystkim nieruchomości.

\section{PRYWATYZACJA NIERUCHOMOŚCI ROLNYCH}

Jednym z elementów kształtowania nowych warunków gospodarczych było stworzenie zasad zarządzania nieruchomościami rolnymi Skarbu Państwa.

Na podstawie ustawy z 19 października 1991 r. o gospodarowaniu nieruchomościami rolnymi Skarbu Państwa ${ }^{28}$ została powołana Agencja Własności Rolnej Skarbu Państwa. Miała ona za zadanie przejęcie, zrestrukturyzowanie i sprywatyzowanie mienia po byłych Państwowych Gospodarstwach Rolnych, nieruchomości rolnych Państwowego Funduszu Ziemi, a także innego mienia rolnego stanowiącego własność Skarbu Państwa. Na podstawie przepisów ustawy o ubezpieczeniu społecznym rolników Agencja została także zobowiązana do przejmowania na własność Skarbu Państwa nieruchomości rolnych, wchodzacych w skład gospodarstw rolnych, na wniosek właścicieli, którzy mają ustalone prawo do emerytury lub renty z ubezpieczenia społecznego rolników.

Na mocy powyższej ustawy utworzono z mienia Skarbu Państwa przejętego w trybie ustawy (a więc z nieruchomości rolnych oraz innych nieruchomości pozostałych po likwidacji Państwowych Gospodarstw Rolnych) Zasób Własności Rolnej Skarbu Państwa. Powołanie Agencji oraz jej działalność były uzasadniane koniecznością szybkiego przejęcia mienia rolnego Skarbu Państwa do Zasobu Własności Rolnej Skarbu Państwa oraz koniecznością zrestrukturyzowania tego mienia (szczególnie przejętego po byłych PGR-ach). Agencja miała za zadanie zapewnienie właściwego gospodarowania Zasobem, a docelowo rozdysponowanie mienia na zasadach określonych w ustawie. Działania te miały na celu szeroko rozumianą prywatyzację nieruchomości rolnych, a więc stworzenie nowej struktury właścicielskiej odnośnie do mienia Skarbu Państwa. Celem działań Agencji było bowiem ograniczenie nieracjonalnej koncentracji gruntów oraz uwolnienie ich części z przeznaczeniem na powiększenie gospodarstw indywidualnych, których struktura była do tej pory bardzo rozdrobniona. W konsekwencji przekształcenia nieruchomości rolnych zmierzały do tworzenia warunków sprzyjających efektywnemu gospodarowaniu. Miało to się dokonać przez rezygnację państwa z zarządzania gospodarstwami rolny-

\footnotetext{
${ }^{28}$ Dz. U. Nr 107, poz. 464 ze zm.
} 
mi i wykorzystanie przedsiębiorczości osób podejmujących gospodarowanie na własny rachunek i własne ryzyko. Jednocześnie Agencja spłacała zadłużenie, co odciążyło zobowiązania budżetu.

\section{REPRYWATYZACJA - NIE ROZWIĄZANY PROBLEM}

Prawo do własności obok prawa do życia i wolności jest podstawowym prawem człowieka i stanowi podstawę ładu prawnego, ekonomicznego i społecznego. Polska przed 25 laty jako pierwsza rozpoczynała przemiany ustrojowe w Europie Środkowo-Wschodniej, lecz niestety do dziśs nie uporządkowano u nas stosunków własnościowych. Komunizm w sposób doktrynalny niszczył i likwidował własność prywatna. W tym celu uchwalono kilkadziesiąt ustaw, dekretów, wydawano rozporządzenia i zarządzenia. Pikanterii dodaje fakt, że zapisy zawarte w niektórych z tych aktów osobiście wprowadzał Stalin, w niektórych z kolei istniało zagrożenie karą śmierci dla dawnego właściciela ${ }^{29}$. W sytuacji gdy totalitarny ustrój został potępiony i odrzucony, oczywista i logiczna jest konieczność przywrócenia własności obywatelom, której pozbawiły ich ówczesne władze. Komunistyczne przepisy, na podstawie których odbierano obywatelom ich własność, nie zostały uchylone do dziśs. Występuje tu niespójność polegająca na tym, że z jednej strony deklarowany jest zamiar odchodzenia od rzeczywistości bezprawia i tworzenia podstaw demokracji, z drugiej zaś - respektowane są dawne przepisy, które w sposób oczywisty służyć miały utrwalaniu totalitarnego ustroju i godziły w wolność i własność obywateli.

Konstytucja III RP odcina się od okresu łamania praw obywatelskich i gwarantuje poszanowanie prawa własności. Ustawa zasadnicza jest najwyższym aktem prawnym i zgodne z nią winny być ustawy zwykłe. Pozostawanie w obiegu prawnym przepisów wydanych w okresie komunizmu, które z samego założenia miały łamać zasady demokratyczne, jest dużym błędem naszej transformacji świadczącym o jej zamazaniu i niejednoznaczności. Demokratyczne państwo prawne opiera się na poszanowaniu niezbywalnych naturalnych praw obywatelskich. Dlatego oczywiste jest, że w sposób jednoznaczny musi odnosić się do prawa własności. Dwudziestopięcioletnia zwłoka w załatwieniu tego problemu dowodzi, że w niektórych obszarach życia publicznego teoria rozminęła się z praktyką. Nowych przepisów, które pozwoliłyby na naprawienie skutków stosowanego przez władze komunistyczne bezprawia w sferze majątkowej, jak dotąd nie wydano.

\footnotetext{
${ }^{29} \mathrm{~Np}$. w rezultacie wytycznych zawartych w uchwale Rady Ministrów z 13 grudnia 1945 r., w której wyrażono konieczność zaostrzenia kar za wszelką działalność podrywającą spokój, porządek i bezpieczeństwo wewnątrz kraju, jak i osłabiającą Polskę na zewnątrz, powstał dekret z 13 czerwca 1946 r. o przestępstwach szczególnie niebezpiecznych w okresie odbudowy Państwa, zwany małym kodeksem karnym, który dopuszczał stosowanie kary śmierci w wymienionych przypadkach, m.in. za wprowadzenie w błąd władzy polskiej przez udzielenie jej fałszywych wiadomości lub dostarczenie podrobionych dokumentów lub innych przedmiotów (art. 8 § 1 i 2 ), co odnieść można było także do spraw związanych z własnością (Dz. U. z 12 lipca 1946 r., Nr 30, poz. 192).
} 
$\mathrm{Na}$ podstawie obecnie obowiązujących przepisów pochodzących z okresu PRL, nie wszyscy wywłaszczeni mogą dochodzić swoich praw. Zachwiana jest więc równość obywateli względem prawa. Uznanie oczywistego bezprawia za stan legalny jest sprzeczne $\mathrm{z}$ istotą państwa prawa. Wydaje się, że istotna przyczyną takiego stanu jest uporczywe trzymanie się poglądów opartych na Austinowskiej wizji „prawa-rozkazu”, mimo iż prawo to służyło ograniczeniu suwerenności państwa i było narzędziem drastycznego łamania naturalnych praw człowieka. Wyrażany szacunek dla takich przepisów, niechęć przed podjęciem ich oceny aksjologicznej niezwykle komplikują problem reprywatyzacji. W Polsce przekształcenia własnościowe, w tym i prywatyzacja, nie zostały poprzedzone zadośćuczynieniem za krzywdy, jakie spotkały obywateli z tytułu odebrania im mienia. Zadośćuczynienie takie jest powszechnie określane pojęciem „reprywatyzacji”, choć należy mieć świadomość, że w wielu przypadkach będzie to już tylko realizacja przysługujących praw odszkodowawczych. Reprywatyzacja jest więc pojęciem umownym, przez które rozumie się naprawienie krzywd wynikających z zaboru własności niezależnie, czy jest ono realizowane $\mathrm{w}$ formie restytucji mienia, czy też przyznania odszkodowania. Reprywatyzacja ma wiele aspektów. Można tu wskazać aspekt moralny, prawny, społeczny, ekonomiczny, czy też polityczny. Niestety w Polsce z wymienionych aspektów wyjątkowe znaczenie zyskał ten ostatni.

Różne siły polityczne w sposób wygodny dla siebie przedstawiają problematykę reprywatyzacyjna. Praktyka pokazała, że prawo własności stało się elementem gry politycznej. Problem respektowania podstawowego prawa człowieka służył do przerabiania go na polityczną monetę. Sprawujący po 1989 r. władzę nie potrafili bądź świadomie nie chcieli zająć zdecydowanego stanowiska w sprawie naprawienia wyrządzonych obywatelom przez państwo krzywd. Politycy nie wykazali niezbędnej determinacji, udowadniając tym, że nie zrozumieli znaczenia reprywatyzacji dla Polski. Problem ten traktowano instrumentalnie. Jałowe spory, sztucznie wywoływane dywagacje powodowały, że dany Polsce przez historię czas, przysłowiowe pięć minut na rzetelna transformacje ustrojowa, bezpowrotnie uciekał, podczas gdy stwarzano warunki prawne dające możliwości uwłaszczania się na mieniu, do którego słuszne roszczenia zgłaszali dawni właściciele.

Reprywatyzacja dla wielu była przeszkodą w osiagnięciu własnych celów lub własnej wizji państwa i panujących w nim stosunków własnościowych. Takie postawy trafiały na podatny grunt. Pięćdziesięcioletnia indoktrynacja społeczeństwa ciagle przynosi rezultaty. Pieczołowicie kształtowana przez kolejne rządzące ekipy komunistyczne mentalność sprawiła, że wielu obywatelom trudno jest oderwać się od wyuczonych stereotypów i uprzedzeń. To powoduje, że wielu nie potrafiło zrozumieć, czym jest prawo własności w państwie demokratycznym. Do dziśs pokutują fałszywe mity zakorzenione w świadomości społecznej przez specjalistów tzw. frontu ideologicznego. W świadomości wielu Polaków zakorzeniły się cechy charakterystyczne dla homo sovieticus,

30 S. Wronkowska, Z. Ziembiński, Zarys teorii prawa, Poznań 2001; L. Leszczyński, Zagadnienia teorii stosowania prawa. Doktryna $i$ tezy orzecznictwa, 2001, admisum.files.wordpress. com/2010/.../zarys-teorii-i-filozofii-prawa-1 (dostęp: 18.02.2014). 
a oderwanie się od tego rodzaju mentalności okazuje się trudne. Często ludzie twierdza, że należy szanować prawo własności, opowiadają się za koniecznościa przeprowadzenia reprywatyzacji, a jednocześnie zaznaczaja, iż procesem tym nie należy obejmować dużej własności. Jest to swoisty paradoks. Prawo do posiadania mienia jest prawem, niezależnie od wielkości własności. W najnowszych dziejach Polski proces zadośćuczynienia za krzywdy majątkowe był już przeprowadzany. Przed II wojną światowa państwo rekompensowało właścicieli i ich spadkobierców, których własności pozbawiły państwa zaborcze. Zasady tego procesu określiła ustawa z 1932 r., uzupełniona dodatkowo rozporządzeniem z 1937 r. Tworzone po 1989 r. kolejne projekty ustaw o reprywatyzacji pozostawały jedynie projektami. Brakowało woli politycznej i koniecznego zdecydowania, by stały się one obowiązującym prawem. Procesy nacjonalizacyjne przeprowadzone w poprzedniej formacji ustrojowej w sposób bezceremonialny naruszały prawo. Naruszenia te można zakwalifikować do trzech grup:

- Do pierwszej grupy zaliczyć należy przypadki tworzenia „nielegalności” aktów wywłaszczeniowych z ówcześnie obowiązującym porządkiem prawnym np. z konstytucją lub z obowiązującymi ogólnie zasadami.

- Druga grupa obejmuje przypadki niewykonania zobowiązań ustawowych państwa wobec obywateli w zakresie ich rekompensowania, przez co zostali oni pozbawieni przysługujacych im odszkodowań.

- Do trzeciej grupy wreszcie zakwalifikować należy wręcz dowolność stosowania przepisów, w tym również prawa wstecz, co stanowi niedopuszczalne łamanie podstawowych zasad porządku prawnego.

Zasady państwa prawa oraz obowiązek poszanowania podstawowych praw człowieka wymagaja, aby proces reprywatyzacji objął wszystkie przypadki naruszeń prawa.

Po roku 1989 wiele mienia, do którego były złożone roszczenia prawowitych właścicieli, zostało sprzedane osobom trzecim. Charakterystyczny był też opór samorządów przed zwrotem mienia, którym samorządy uwłaszczono. A przecież gminy otrzymały je od państwa tytułem darmym i powinny uczestniczyć w procesie odszkodowawczym. Przeniesienie praw i obowiązków poprzednich podmiotów dysponujących mieniem państwowym na jednostki komunalne powoduje, że występuje tu sytuacja podobna jak przy sukcesji generalnej, odnoszacej się do określonego mienia. W tej kwestii wielokrotnie wypowiadał się również Trybunał Konstytucyjny, dopuszczając możliwość uszczuplenia praw majątkowych przysługujących jednostkom samorządu terytorialnego, o ile pozostaje ono $\mathrm{w}$ zgodzie z założeniami aksjologicznymi leżącymi u podstaw przepisów i zasad konstytucyjnych. W ocenie Trybunału jednostki samorządu terytorialnego muszą więc liczyć się z koniecznością ponoszenia części kosztów reform związanych z realizacja przemian ustrojowych ${ }^{31}$. Przyjęcie innej koncepcji powoduje, że gmina stanowić będzie konkurencję dla obywatela w odniesieniu do realizacji jego prawa obywatelskiego. Dopuszczenie do tego

${ }^{31}$ Wyrok Trybunału Konstytucyjnego z 12 kwietnia 2000 r., K. 8/98, Dz. U. 2000, Nr 28, poz. 352 . 
stanowiłoby złamanie zasad państwa prawnego, zaprzeczenie samorządności i podważyłoby podmiotowość obywatela w państwie prawnym.

Jedynie w okresie rządów premiera Jerzego Buzka udało się stworzyć projekt ustawy reprywatyzacyjnej, który został uchwalony przez parlament. Niestety ówczesny prezydent Aleksander Kwaśniewski zgłosił veto, mające głównie charakter ideologiczny i polityczny ${ }^{32}$. Warto wspomnieć, że ustawę Rada Legislacyjna uznała za jeden z najlepszych aktów prawnych przygotowanych w III RP ${ }^{33}$. Dlatego też dziwiło uzasadnienie veta prezydenta, w którym stwierdzono, że był to akt pod względem prawnym zły. Fakt ten należy raczej uznać za socjotechniczny zabieg o podłożu politycznym, zastosowany na użytek chwili. Szansa, jaka stworzył wtedy układ polityczny po raz pierwszy w okresie 12 lat transformacji, została zmarnowana.

Znaczacca część zgłoszonych wszystkich roszczeń to tzw. roszczenia zabużańskie. Dotyczą one osób, które zostały na mocy układów poczdamskich przesiedlone ze wschodnich ziem przedwojennego państwa polskiego przejętych przez ZSRR na ziemie zachodnie przyłączone do Polski w wyniku II wojny światowej. Pomimo jednoznacznej sytuacji prawnej tworzone przeszkody nie pozwalają wielu uprawnionym na zrealizowanie przysługujaccego im prawa. Podstawę uprawnienia stanowią ustalenia konferencji poczdamskiej oraz umowy międzynarodowe określające status wysiedlonych. W ślad za nimi wydano kilka następujących po sobie dekretów i ustaw, począwszy od $1946 \mathrm{r}$. a na ustawie z 2005 r. skończywszy, precyzujących sposób realizacji tego prawa. Uprawnienia tej grupy obywateli były przedmiotem orzeczeń Sądu Najwyższego, podniesionych do rangi zasad prawnych, jak również orzeczeń Trybunału Konstytucyjnego. Teoretycznie nie istniały więc przeszkody $\mathrm{w}$ realizacji przedmiotowego prawa, w praktyce jednak uniemożliwiano ich realizację. Niestety wyniesione z okresu PRL uprzedzenia do tej nielubianej przez ówczesne władze grupy obywateli, którzy doświadczyli w sposób wyjątkowy w praktyce komunistycznej rzeczywistości, przeniosły się do tradycji III RP. Dopiero po przegranej Polski przed Trybunałem w Strasburgu uchwalono w 2005 r. ustawę dla tej grupy obywateli ${ }^{34}$.

Reprywatyzacja mienia osób fizycznych to niejedyny problem. Komunistyczne władze odebrały też majątek osobom prawnym. Ta kwestia też wymagała rozwiązania. Po 1989 r. uchwalono więc kolejne ustawy dotyczące zwrotu mienia poszczególnym Kościołom funkcjonujacym w Polsce. Proces restytucji i odszkodowań w tym zakresie trwa. Nastapiło więc złamanie zasady równości prawnej, gdyż przyznaje się rekompensaty osobom prawnym, a nie dopuszcza do tego procesu osób fizycznych. Taka dyferencja praw w demokratycznym państwie prawnym jest niedopuszczalna. Innym problemem jest fakt, że komunistyczne władze odebrały też majątek znajdujący się w Polsce, a należący

${ }^{32}$ Ustawa z 7 marca 2001 r. i odmowa podpisania ustawy przez Prezydenta RP (Druk Sejmu nr 2719) oraz Sprawozdanie Komisji Nadzwyczajnej Sejmu o ponowne rozpatrzenie ustawy (Druk nr 2808) z 26 kwietnia 2001 r.

33 „Przegląd Legislacyjny” 1999, nr 2, s. 72.

${ }_{34}$ Ustawa z 8 lipca 2005 r. o realizacji prawa do rekompensaty z tytułu pozostawienia nieruchomości poza obecnymi granicami Rzeczypospolitej Polskiej, Dz. U. z 6 września 2005 r., Nr 169, poz. 1418 ze zm. 
do cudzoziemców. Pod naciskiem państw zachodnich władze PRL w latach 1950-1975 podpisały kilkanaście umów indemnizacyjnych z określonymi państwami, przekazując środki pieniężne w ustalonej wysokości na zaspokojenie roszczeń majątkowych obywateli tych państw. Zaistniała więc sytuacja, w której obywatele obcych państw zostali potraktowani korzystniej przez rząd polski niż Polacy. Obowiązkiem każdego państwa i jego władz jest przede wszystkim dbałość o swoich obywateli, wyrażająca się w poszanowaniu podmiotowości każdej jednostki. Dopuszczenie do takiego stanu określa jednoznacznie charakter tamtej władzy i jej stosunek do obywatela. Uraga on zasadom państwa prawnego i stosunkom obywatel-państwo.

W świetle powyższych faktów brak załatwienia wstydliwego już dziś problemu reprywatyzacji kładzie się cieniem na korzystnym przecież 25 -leciu wolności.

Zgłaszając veto do ustawy reprywatyzacyjnej, ówczesny prezydent odesłał poszkodowanych właścicieli do sądów. Było to bardzo ryzykowne posunięcie. Zniecierpliwieni dawni właściciele coraz częściej zaczęli korzystać z tej rady. Obowiązujące do dziś w Polsce prawo, ustanowione przez komunistyczne władze w celu zachowania pozorów legalności, pozwala części dawnych właścicieli dochodzić swoich praw. Polskie orzecznictwo, dostosowujace się do ogólnie uznanych zasad orzecznictwa demokratycznych państw prawnych, możliwości dochodzenia roszczeń we wspomnianym trybie coraz bardziej poszerza. Obowiązujące procedury nie są jednak dostosowane do dzisiejszej rzeczywistości, co powoduje nowe napięcia i wieloletnie przeciaganie się spraw. Z tego powodu zaistniały już niekorzystne dla Polski precedensy w postaci orzeczeń Trybunału w Strasburgu. Rezultatem wygranych przez poszkodowanych właścicieli postępowań jest zasądzanie wysokich odszkodowań obciążających bezpośrednio budżet. Skala tych wypłat jest coraz większa. Brak w budżecie środków na ten cel powoduje eskalację łamania praw obywatela. Tę sytuację bardzo wyraźnie można zaobserwować w Warszawie jako konsekwencję osławionego dekretu Bieruta ${ }^{35}$. Wzbudza to u wielu obywateli niewiarę w zasady państwa prawnego.

Warto też wskazać na odpowiedzialność odszkodowawczą państwa za działanie władzy publicznej. Sądy powszechne już dzisiaj obowiązane sa do samodzielnego orzekania o odpowiedzialności Skarbu Państwa w tym zakresie. Podstawa jest tu art. 77 Konstytucji. Kwestia legislacyjnego bezprawia zdarzała się również w czasach przed II wojną światową. Przykładem może być orzeczenie całej Izby Pierwszej Sądu Najwyższego z 12 maja 1928 r. (I C 592/26, Zb. Orz. 1928, poz. 98): „Wszelkie akty władzy rosyjskiej, czy to ustawodawcze, czy to wykonawcze, na których oparta była i za których pomoca dokonana została konfiskata mienia, nie były aktami prawa, lecz przejawami bezprawia, wynikającymi z zaprzeczenia Narodowi Polskiemu, najistotniejszego jego prawa, jakiem jest prawo do samodzielnego bytu państwowego".

$\mathrm{Z}$ bezprawiem legislacyjnym nierozerwalnie związana jest odpowiedzialność państwa za szkody poniesione przez obywateli, będące wynikiem tego

${ }^{35}$ Dekret z 26 października 1945 r. o własności i użytkowaniu gruntów na obszarze m. st. Warszawy, Dz. U. z 21 listopada 1945 r., Nr 50, poz. 279. 
typu działania władzy ustawodawczej. Dlatego już w Konstytucji marcowej z 1921 r. ustanowiono w art. 121, że „Każdy obywatel ma prawo do wynagrodzenia szkody, jaką mu wyrządziły organy władzy państwowej, cywilnej lub wojskowej, przez działalność urzędowa, niezgodna z prawem lub obowiązkami służby. Odpowiedzialnym za szkodę jest Państwo solidarnie z winnymi organami; wniesienie skargi przeciw Państwu i przeciw urzędnikom nie jest zależne od zezwolenia władzy publicznej”.

Również w Konstytucji z 1997 r. w art. 77 ust. 1 stanowi się, że: „Każdy ma prawo do wynagrodzenia szkody, jaka została mu wyrządzona przez niezgodne z prawem działanie organu władzy publicznej” oraz że „Ustawa nie może nikomu zamykać drogi sądowej dochodzenia naruszonych wolności lub praw" (ust. 2). Szczegółową wykładnię tego przepisu przeprowadził Trybunał Konstytucyjny w wyroku z 4 grudnia 2001 r. (SK 18/00) dotyczaccym art. 418 i 417 k.c.

Warto przypomnieć niektóre przykłady. W pierwszej kolejności są tzw. zaniechania legislacyjne. Przykład taki wskazał NSA w głośnym wyroku z 5 lutego 2003 r. (IV SA 2854/01). Stwierdził w nim, że wskutek zaniechania legislacyjnego Rady Ministrów (tj. niewydania rozporządzenia wykonawczego do ustawy z 3 stycznia 1946 r. o przejęciu na własność państwa podstawowych gałęzi gospodarki narodowej) zamknięta została droga sądowa i administracyjna do dochodzenia odszkodowania za znacjonalizowane przedsiębiorstwa. Podobnie jest z dekretem z 25 października 1945 r. o gruntach warszawskich. Przyznał on w art. 9 wszystkim właścicielom znacjonalizowanych gruntów warszawskich stosowne odszkodowanie. Jednakże sposób jego ustalania miało określić rozporządzenie. Nie zostało ono nigdy wydane, a ustawa z 1985 r. o gospodarce gruntami i wywłaszczaniu nieruchomości wygasiła roszczenia odszkodowawcze nabyte na podstawie dekretu, mimo że poszkodowani nigdy nie mieli możliwości dochodzenia odszkodowania.

Polska jest dziś jedynym państwem Europy Środkowo-Wschodniej, które nie uporządkowało stosunków własnościowych. Pozostałe państwa wychodzące z komunizmu proces ten mają za soba. Dla przykładu w Czechach uchwalono sześć ustaw reprywatyzacyjnych, zwracając mienie niezależnie od jego wielkości i rodzaju. Podobne założenia przyjęto w Rumunii, Macedonii czy w państwach bałtyckich.

Przeobrażeń w życiu publicznym nie można przeprowadzać z pominięciem oczywistych i podstawowych zasad, które stymulują tworzenie wartości państwa prawa. Transformacja ustrojowa zmusza do dokonania takich zmian, które będą służyć budowaniu systemu prawnego opartego na nienaruszalnych i niezbywalnych prawach przysługujących człowiekowi. W przeciwnym razie następuje dalsze ograniczanie praw obywatela i umacnianie omnipotencji państwa wyrażajace się m.in. w arbitralnie ustalanym prawie własności. Nie godząc się z totalitarnym ustrojem, odcinano się od takiej relacji między państwem a obywatelem. Dlatego też problem reprywatyzacji wykracza poza literalną formułę własności. Transformacja ustrojowa bez rozwiązania tej kwestii jest procesem niepełnym. Negatywne konsekwencje tego stanowią balast w rozwoju naszego państwa. 


\section{PODSUMOWANIE}

Wprowadzenie w roku 1989 demokratycznego ustroju, przejście od gospodarki centralnie sterowanej do wolnorynkowej oraz podjęcie szerokich reform o charakterze prawnym, gospodarczym i społecznym spowodowało ukształtowanie się nowego systemu, którego zręby przez ostatnie 25 lat utrwaliły się. W tym czasie daleko idących zmian doczekał się także system bankowy oraz polityka pieniężno-kredytowa. Prowadziło to do otwarcia rynku na kapitał zagraniczny, który z biegiem lat, w coraz większym stopniu był i jest zainteresowany inwestowaniem w Polsce. Kraj nasz jest postrzegany jako stabilny, a to, że Polska wyszła obronną ręką z kryzysu gospodarczego, który od 2008 r. nękał wysoko rozwinięte państwa świata, w tym także naszych partnerów z Unii Europejskiej, spowodowało wzrost zaufania inwestorów do zaangażowania w polska gospodarkę. Ogromne znacznie miały dla niej wspomniane wyżej przekształcenia własnościowe, dzięki którym, stopniowo, większość przedsiębiorstw z państwowych stała się prywatnymi. Transformacja systemowa pozwoliła na rozwój polskiej małej i średniej przedsiębiorczości - w rezultacie powstawania nowych, prywatnych podmiotów gospodarczych ich liczba wzrosła kilkukrotnie: z 1,2 mln w 1990 r. do 4 mln zarejestrowanych na koniec 2012 r., z czego prawie 96\% stanowią mikrofirmy ${ }^{36}$. W 2012 r. w Polsce przybyło 358 tys. nowych podmiotów gospodarczych. Co warte podkreślenia, wśród nich zdecydowanie dominowały osoby fizyczne prowadzace działalność gospodarczą (80\% ogółu). W sektorze prywatnym pracuje obecnie ok. $69,3 \%$ zatrudnionych $^{37}$.

$\mathrm{Z}$ jednej strony ta radykalna zmiana gospodarcza spowodowała, że nasze firmy coraz lepiej radzą sobie w gospodarce wolnorynkowej, z drugiej zaś - przyczyniła się do powstania kapitałowego rynku pracy, z jego jasnymi i ciemnymi (bezrobocie) stronami. Warto wspomnieć, że w 2013 r. Polska zajęła pierwsze miejsce wśród państw należących do OECD i wśród państw Unii Europejskiej pod względem postępu we wdrażaniu od 2005 r. reform ułatwiających prowadzenie biznesu (14 miejsce w ogólnoświatowym rankingu $)^{38}$.

Mimo wielu pozytywnych przemian i osiagnięć gospodarczych i społecznych ostatniego ćwierćwiecza, związanych także z przekształceniami własnościowymi, trzeba pamiętać, że Polskę czeka jeszcze wiele wyzwań. Sa one związane m.in. ze strefą finansów publicznych (przede wszystkim dotyczy to zmniejszenia deficytu budżetowego), z rynkiem pracy i z bezrobociem (zwłaszcza osób młodych i starszych), z wymagającą zmian edukacją na różnych poziomach nauczania, z nieefektywną służbą zdrowia i z przerośniętą administracją publiczną z innowacyjnością i konkurencyjnością gospodarki na globalnym rynku oraz z utrzymaniem zaufania inwestorów. I w końcu, trzeba

\footnotetext{
${ }^{36}$ Przedsiębiorczość w Polsce (2013), Ministerstwo Gospodarki, Warszawa, wrzesień, s. 7.

${ }_{37}$ Zagospodarowane i niezagospodarowane miejsca pracy w III kwartale 2013 r., GUS, www. gus.gov.pl (dostęp: 30.01.2014).

${ }^{38}$ Ease of Doing Business 2013, www.doingbusiness.org (dostęp: 30.01.2014).
} 
rozwiązać problem roszczeń reprywatyzacyjnych. Nie sa to na pewno zadania łatwe, ale ukształtowany w ostatnich 25 latach demokratyczny system wolnorynkowy daje szansę na ich stopniową realizację.

dr Krzysztof Hubert Easzkiewicz

Sekretarz Stanu w Kancelarii Prezydenta RP

\section{CHANGES IN OWNERSHIP RELATIONSHIPS IN POLAND AFTER 1989}

\section{Sum mary}

This paper presents structural changes that took place in Poland after 1989, and which enabled its transition from a centrally planned economy to a market economy. The deep and thorough legal, economic and social reforms undertaken in that period made it possible, after years of communist rule, to shape a new, democratic system. The systemic transformation was possible owing to some basic amendments to the Constitution, including the articles defining the essence of ownership and the duty to respect it, as well as the adoption of other legal acts necessary to re-define ownership relationships (such as the law on commercialisation and privatisation of state-owned enterprises, or the law on the management of agricultural property). The concurrent reforms of the banking system and the monetary and credit policy enabled inflow of foreign capital and development of private entrepreneurship. As a result of the transformations of the past 25 years, Poland is now a democratic state and a member of the European Union, while Polish economy is getting increasingly competitive. Sadly enough, despite these substantial structural transformations in the ownership sphere, in the last quarter of the century Poland has continued to be unable to resolve the problem of returning to the lawful owners the property taken by the communist regime. 
Copyright of Journal of Law, Economics and Sociology is the property of Faculty of Law and Administration of Adam Mickiewicz University in Poznan and its content may not be copied or emailed to multiple sites or posted to a listserv without the copyright holder's express written permission. However, users may print, download, or email articles for individual use.

Właścicielem praw autorskich do „Ruchu Prawniczego, Ekonomicznego i Socjologicznego” jest Wydział Prawa i Administracji Uniwersytetu im. Adama Mickiewicza w Poznaniu. Zawartość czasopisma nie może być kopiowana, przesyłana do innych stron internetowych bądź zamieszczana na blogach bez pisemnej zgody wydawcy. Niemniej artykuły można drukować, kopiować lub przesyłać w formie elektronicznej na własny użytek. 